\title{
ANTICIPATORY REPUDIATION: ANACHRONISTIC LIMITATIONS
}

$\mathbf{T}$ HE RIGHT to recovery for anticipatory breach of contract was first authoritatively enunciated in Hochster v. De la Tour, where it was announced that a party to an executory bilateral contract who repudiates it before the agreed time of performance becomes liable immediately for the full value of the promised performance. ${ }^{2}$ This rule, which has been substantially followed in virtually every jurisdiction, contains two significant limitations: the contract involved must be bilateral, and the promised performance that has failed must not be solely for the payment of money. ${ }^{3}$

These limitations on the right of recovery for anticipatory breach were recently re-examined in Phelps v. Herro, ${ }^{4}$ where the defendant, after having made an initial payment, unequivocally announced his refusal to execute promissory notes for further payment for fractional interests in real estate which had been transferred to him by the plaintiff pursuant to contract. The Maryland Court of Appeals held that the doctrine sanctioning damages for an anticipatory breach of

\footnotetext{
12 El. \& Bl. 678,118 Eng. Rep. 922 (Q.B. 1853 ).

2 "[Upon] a contract to do an act on a future day, a renunciation of the contract by one party dispenses with a condition to be performed in the meantime by the other, there seems no reason for requiring that other to wait till the day arrives before seeking his remedy by action: and the only ground on which the condition can be dispensed with seems to be, that the renunciation may be treated as a breach of contract." Hochester v. De la Tour, supra note $I$ at 694,118 Eng. Rep. at 928.

${ }^{3}$ Restatement, Contracts $\$ 318$ (1948 Supp.) provides: "In the case ( $\mathrm{x}$ ) of a bilateral contract that has not become unilateral by full performance on one side, and (2) of a unilateral contract where the agreed exchange for the promise or for its performance has not been given, any of following acts, done without justification by a promisor in a contract before he has committed a breach uuder the rules stated in $\S \S 314-315$, constitutes an anticipatory repudiation which is a total breach of contract:

(a) a positive statement to the promisee or other person having a right under the contract, indicating that the promisor will not or cannot substantially perform his contractual duties;

(b) Transferring or contracting to transfer to a third person an interest in specific land, goods, or in any other thing essential for the substantial performance of his contractual duties;

(c) any voluntary affirmative act which renders substantial performance of his contractual duties impossible or apparently impossible."

'215 Md. 223, 137 A.2d 159 (1957).

" 137 A.2d at 164: "We think the proper rule is that the doctrine of anticipatory breach of a contract has no application to money contracts, pure and simple, where
} 
contract was inapplicable ${ }^{5}$ despite a vigorous dissent which noted: ${ }^{0}$

Essentially I dissented because I could not bring myself . . . to saddle Maryland needlessly with what I consider to be illogical and unsound law-a doctrine that is more apparent than real, and one that has been repudiated by the ablest judges and scholars.

There are two reasons that largely explain the continued vitality of these limitations. ${ }^{7}$ First, Hochster v. De la Tour, through repeated

one party has fully performed his undertaking, and all that remains for the opposite party to do is to pay a certain sum of money at a certain time or times, and, under the circumstances of this case, this is as far as we need to rule, although some of the cases cited hold that the doctrine of anticipatory breach has no application whatsoever in unilateral contracts, or bilateral contracts that have become unilateral by full performance on one side."

${ }^{6}$ The dissenting judge aptly pointed out that the Maryland authorities tend more to refute than support the majority contentions. The court relied most heavily on two cases: Appleman v. Michael, 43 Md. 269 (1875); Precision Development Co. v. Fast Bearing Co., 183 Md. 399, 37 A.2d 905 (1944).

The Appleman case involved the defendant's refusal to execute a ninety-day promissory note in payment for goods already delivered. The court allowed recovery on the apparent rationale that the goods were not sold on condition that the note be executed, but that the sale was merely an ordinary credit transaction. Notwithstanding the fact that the court said, "We are clearly of. [the] opinion that no action for their [the goods'] walue could under any circumstances, have been sustained if brought before the [time of performance]," Appleman v. Michael, supra at 28I, no significant distinction can be ascertained between that case and the principal case of Phelps v. Herro, $215 \mathrm{Md}$. 223, 137 A.2d 159 ( 1957 ).

Recognizing this fact, the dissenting judge noted: “. . . the suit there [in the Appleman case] actually entered was one for the value of the goods sold and was not one for the breach of contract to execute the note that was to be given in payment for the goods." I37 A.2d at 567 . (Einphasis added.) The court in the Appleman case conceded that the vendor would be able to bring a special action for damages for breach of contract to execute the note and recover "... such damages as the jury might have thought reasonable. ..." Appleman v. Michael, suppra at 280 . As the dissenting judge pointed out, "... that is precisely what the plaintiff sought in the case before us, damages for breach of contract to give the note." Phelps v. Herro, supra, 137 A.2d at 167 .

Precision Development Co. v. Fast Bearing Co., supra, invloved the sale of certain chattels with initial payment within 30 days and the remainder in 5 annual installments, the balance to be secured by a chattel mortgage. After acceptance of the goods, the defendant refused to execute the chattel mortgage. Thus, the facts involved are strikingly similar to those in the instant case. The majority opinion in the Herro case distingnished the Precision Development Co. case on the ground that the case at bar did not involve ". . . an agreement to secure the notes in any manner whatsoever, but the agreement of the appellants was a bald promise to pay money at a future date." Phelps v. Herro, supra, 137 A.2d at 164 . Notwithstanding the fact that the Precision Development Co. case did involve security and was not a mere "bald promise," the contract had become wholly unilateral and the suit was for recovery of the purchase price. This is the exact situation found in the Herro case.

${ }^{7} 4$ Corbin, Contracts $\$ \S$ 959-964 (195I); 5 Williston, Contracts $\$ \S 1313$, 
enunciation, has become so firmly established that none but the most iconoclastic courts would presume to modify it appreciably. ${ }^{8}$ Second, although the doctrine is generally considered to rest on a weak logical foundation, and the courts exhibit a marked reticence to expand the doctrine beyond minimum dimensions, they feel that it must be applied as a matter of practical necessity. ${ }^{9}$

In appraising the utility of these limitations, adversion to the theoretical justification for the doctrine is indispensable. Thus, formation of a contract is said to ${ }^{10}$

... [give] immediately an inchoate right to the performance of the bargain, which becomes complete when the time for performance has arrived, giving, in the meantime, a right to have the contract kept open as a subsisting and effective contract....

Surely, however, the same can be said of any contract, bilateral or unilateral. Unqualified repudiation by the promisor will depreciate the value of any obligation. This reasoning, in fact, renouncing the traditional limitation, has found its way into occasional aberrant decisions. ${ }^{11}$ Another theory of contract asserts that at the time of integration the parties impliedly promise that they will do nothing to detract

1314, 1328, 1330B (rev. ed. 1937); Ballantine, Anticipatory Breach and the Enforcement of Contractual Duties, 22 Mich. L. Rev. 329 (1923).

${ }^{8}$ Ballantine, supra note 7; Comment, 44 Mich. L. Rev. 163 (1945); Note, 4 ORLA. L. REV. II2 (I95I).

“... [I]f, as has been argued... the whole doctrine was founded on a confusion of a right of action with a defense, it seems undesirable to enlarge the boundaries of the doctrine." 5 Williston, CoNTrActs $\$$ 1328 (rev. ed. r937).

Several eminent jurists have taken a contrary position. Judge Learned Hand, in the case of Equitable Trust Co. of New York v. Western Pacific Ry. Co., 244 Fed. 485 , 50I (D.C.N.Y. I9I7), attacks the limitations on the doctrine in the following words: "[If] performance remains mntually executory, the doctrine still applies, even though the promise is only to pay inoney. ... If the doctrine has any limits, they only exclude, and that arbitrarily enough, cases in which at once the promisee has wholly performed, and the promise is only to pay money.

"Assuming as I do not mean to admit, that it has such limits, they result because the eventual victory of the doctrine over vigorous attack . . . has not left it scatheless...."

Mr. Justice Cardozo also criticized the limitations in New York Life Insurance Co. v. Viglas, 297 U.S. 672 (1936).

${ }^{30}$ Frost v. Knight, L.R. 7 Ex. III (1872). Professor Williston believes that this explanation is "fanciful" because, "if true the action should be brought for breach of a promise to have the contract kept open." 5 Williston, Contracts $\S$ I 320 (rev. ed. r937).

${ }_{11}$ Williams v. Mutual Benefit Health and Accident Association, 10o F.2d 264 (5th Cir. 1938); Pollack v. Pollack, 39 S.W.2d 853 (Tex. Civ. App. I931).

Pollack v. Pollack, supra, is perhaps the leading case in this respect. Professor Williston has devoted an entire section in his work to its discussion. He maintains 
from the efficacy of the obligation. ${ }^{12}$ Therefore, for reasons of judicial convenience, the victim of repudiation is said to have the right to immediate redress, since he no longer has reasonable expectation that the other party will perform his bargain.13 Each of these theories embraces the essence of the doctrine of anticipatory breach of contract, and absent further rationalization, it seems obvious that a party to any contract is interested in preserving its integrity, irrespective of its categorization as bilateral or unilateral.

Another anomaly appears upon consideration of the second limitation -i.e., exclusion of money contracts. ${ }^{14}$ Significantly enough, the bulk of American case law which is relied upon as authority here does not involve money. Many ${ }^{15}$ of these cases, moreover, do not even contain true anticipatory breach situations. ${ }^{18}$ Illustrative is Roehm v. Horst ${ }^{17}$ which was an action for breach of four certain contracts for the periodic delivery of beerhops over a five year term. Up to the time of the

that the case is ". . . an illustration of the length to which the doctrine of anticipatory breach of contract can be stretched." 5 WiLliston, Contracts § $1330 \mathrm{~B}$ (rev. ed. I937).

Among numerous articles published on the Pollack case are: Note, 45 HARv. L. REv. 585 (1932); Note, Io TexAS L. REv. 236 (1932).

${ }_{12}$ See Equitable Trust Co. v. Western Pacific Ry. Co., 244 Fed. 485 (D.C.N.Y. 1917); 5 WILliston, Contracts $\$ 1318$ (rev. ed. 1937):

${ }^{18}$ See Note, 4 OKLA. L. REv., 112,113 (1951), wherein it is stated: "A . . . suggested basis for the doctrine is that of practical convenience afforded by a prompt disposition of litigation. Obviously, any such practical convenience is not dependent upon the type of contract but would exist in the case of either a bilateral or unilateral obligation."

Professor Williston asserts: "The reason most strongly urged in support of the doctrine of anticipatory breach is, however, its practical convenience. It is said that if it is certain that the plaintiff is going to have an action, it is better for both parties to have it disposed of at once." 5 WILliston, ConTracts $\$ 1321$ (rev. ed. 1937).

It See Comment, 22 MicH. L. REv. 329, 351 (1923) where it is stated: "The lack of logic in refusing to apply this doctrine to notes, bonds and the like should be corrected by the courts even without the aid of legislation. If there be any rational theory of anticipatory breach it should cover the total repudiation of debts, and give an immediate right of action to enforce the obligation. ..."

${ }^{15}$ Washington County v. Williams, 111 Fed. 801 (8th Cir. 1901); Mannheimer v. NederIandsche Amerikaansche Stomvaart Maatschappij, 6 F. Supp. 564 (D.C.S.D.N.Y. 1934); Leon v. Barnsdall Zinc Co., 309 Mo. 276, 274 S.W. 699 (1925), reversing, 247 S.W. ${ }_{1013}$ (Mo. App. 1923); Manufacturers' Furniture Co. v. Cantrell, 172 Ark. 642,290 S.W. 353 (1927).

${ }^{10}$ Roehm v. Horst, 178 U.S. I ( 1900$)$; Brimmer v. Union Oil Co., 81 F.2d 437 (10th Cir.), cert. denied, 298 U.S. 668 (1936); Moore v. Security Trust \& Life Ins. Co., 168 Fed. 496 (8th Cir. 1909), cert. denied, 219 U.S. 583 (1910); Huffman v. Martin, $226 \mathrm{Ky}$. 137, ro S.W.2d 636 (1928); Fidelity \& Deposit Co. v. Brown, 230 Ky. 534, 20 S.W.2d 284 (1929).

${ }_{17} 18$ U.S. I (1900). 
alleged repudiation, 600 of the promised $\mathrm{I}, 000$ bales of merchandise had been delivered and paid for. Mr. Justice Fuller, writing for a unanimous court, stated $:^{18}$

In case of ordinary money contracts such as a promissory note, or a bond, the consideration has passed; there can be no mutual obligations; and cases of that sort do not fall within the reason of the rule.

Nor did Mr. Justice Fuller include pure money contracts within the "reason of the rule." The ostensible "reason of the rule" is to foster respect for contractual obligations and to extend to the victim of a premature but unequivocal breach a present remedy. ${ }^{10}$ Roehm $v$. Horst leaves unanswered the question, why should the fact that the consideration has passed effectively deprive a promisee of a reasonable expectation that he will be duly recompensed for the consideration he has conveyed? So long as this latter exception to the doctrine governing anticipatory breach of contract is recognized, the only expectancy

\footnotetext{
19. Id. at I7.
}

20 "The reason why a contract to pay money at a definite time in the future is an exception to the rule is that money is not a commodity which is bought and sold in the market and the market value of which fluctuates, as is the case with grain, stocks, and other similar articles." Alger-Fowler Co. v. Tracy, 98 Minn. 432, 437, 107 N.W. 1124,1126 (1906). This reasoning adduced by the Minnesota court fails as "a reason." Money is, in the most literal sense, a commodity which is bought and sold in the market; its price indeed does fluctuate. But a more important weakness in the court's argument is pointed out by Professor Ballantine: "The basis of anticipatory breach generally recognized is the right to have the contract kept open as a subsisting and effective contract, not the uncertainty of the damages or value of the performance." Ballantine, supra note 7 , at $35 x$.

Mr. Justice Cardozo has observed that upon examination of the wealth of cases on anticipatory breach it wonld be found that the rationales for exclusion of money contracts ". . . have stated at times, though with needless generality, that by reason of the subject matter of the undertaking the rule applicable to contracts for the payment of inoney is not the same as that applicable for the performance of services or the delivery of merchandise. . . The root of any valid distinction is not in the difference between money and merchandise or between money and services. What counts decisively is the relation between the maintenance of the contract and the frustration of the ends it was expected to subserve. The ascertainment of this relation calls for something more than the mechanical application of a uniform formula." New York Life Insurance Co. v. Viglas, 297 U.S. 672, 680 (1936).

Professor Corbin suggests that money contracts are often excluded because courts wish to preclude an "Acceleration of the Date of Maturity" aud rejects this contention: "Money due next year cannot be made due now by the debtor's saying that he is not going to pay it. But neither can services that by the contract are to be performed next year be rendered immediately performable by the employee's saying that he is not going to render the service. The same is true with respect to contracts for the sale of goods or the conveyance of land." 4 Corbin, Contracts $\$ 965$ (195x). Cf. 4 Corbin, Contracts $\$ \S 966,967$ (I95 I). 
of a promisee in such situation ${ }^{20}$ is a future law suit. If a particular contract should involve an obligation to pay money in future installments, ${ }^{21}$ the promisee's plight is further confounded in that his redress will necessarily depend upon a series of expensive and relatively unpredictable suits. Yet, it is highly doubtful that there is any less "mutuality of obligation" involved in money contracts than in such other contracts as Mr. Justice Fuller would have conceded to fall "within the reason of the rule."

A genuine practical need for the doctrine of anticipatory breach exists, and has been acknowledged by leading scholars and jurists. Consequently, the judicial toleration of the limitations on the doctrine of anticipatory breach of contract is as anomalous as it is unfortunate and, in the interests of complete justice, ought to be withdrawn. ${ }^{22}$

\footnotetext{
${ }^{20}$ Professor Williston is opposed to allowing immediate recovery because the "premature" recovery would be had at the expense of "logical exactness": "It may be conceded that practical convenience is of more importance than logical exactness, but yet the considerations of practical convenience must be very weighty to justify infringing the underlying principles of the law of contracts. The law is not important solely or even chiefly for the just disposal of the litigated cases immediately before the court." 5 Williston, Contracts $\$ 1321$ (rev, ed. 1937). Professor Corbin takes an opposite view: "The repudiation by the defendant is generally morally indefensible. It disturbs the confidence and security of the promisee; it causes him immediate pecuniary injury; and the allowance of an immediate action makes for an early settlement of the dispute and a timely payment of damages." 4 CORBiN, CoNTrACTS $\$ 961$ (1951).

${ }^{21}$ Hawkinson v. Johnston, 122 F.2d 724 (8th Cir. 1941); Sagamore Corp. v. Willcutt, 120 Conn. 3.15, 180 Atl. 464 (1935); Pollack v. Pollack, 39 S.W.2d 853 (Tex. Civ. App. 1931). See also 4 Corbin, Contracts $§ 966$ (1951); 5 Williston, ConTRACTS \& 1371 (rev. ed.1937).

A policy argument is advanced in the case of Hawkinson v. Johnston, supra at 729: "The commercial world has long since learned the desirability of fixing its liabilities and losses as quickly as possible, and the law similarly needs to remind itself that, to be useful, it too must seek to be practical."

${ }^{23}$ "One does not have to await the consummation of threatened injury to obtain preventive relief. If the injury is certainly impending that is enough." Pennsylvania v. West Virginia, 262 U.S. 553, 593 (1923). "To say that the law cannot logically give any remedy to enforce the contract against the repudiator until he actually carries out his injurious threat seems as pacifistic as to say that a country cannot take any measures to defend itself upon a mere declaration of war, but must wait until it is actually invaded and occupied by the enemy. . . . It is submitted that the doctrine of anticipatory breach is not only supported by its practical convenience, but by strong considerations of justice to the plaintiff; that it does not enlarge the duties of the defendant or hold him liable on a promise he never made." Comment, 22 Mich. L. REv. 329,352 (1923).
} 